\title{
Evaluation of IPM Module for Management of Yellow Vein Mosaic Virus in Okra under Mid-Central Table Land Zone of Odisha
}

\author{
D. Panigrahi ${ }^{1}$, B.C. Dhir ${ }^{1}$, S. Samal ${ }^{1}$, B.K. Routray ${ }^{2}$ and B. K. Pani ${ }^{1}$ \\ ${ }^{1}$ Regional Research and Technology Transfer Station, Mahisapat, Dhenkanal-759013, India \\ ${ }^{2}$ Krishi Vigyan Kendra, Jagatsingpur, Odisha, India \\ *Corresponding author
}

\section{A B S T R A C T}

\begin{tabular}{l} 
Ke y w o r d s \\
IPM module, \\
Yellow vein mosaic \\
virus, Okra, \\
Mid-central table \\
\hline Article Info \\
$\begin{array}{l}\text { Accepted: } \\
\text { 22 June } 2020 \\
\text { Available Online: } \\
\text { 10 July } 2020\end{array}$ \\
\hline
\end{tabular}

Field experiments were conducted during Kharif 2016 and 2017 to manage yellow vein mosaic virus in Okra with seven modules along with one control. The module consists of use of either seed treatment or yellow sticky trap singly or in combination with neem oil (bio-pesticide), one insect growth regulator and two new generation insecticides to manage the vector population of whitefly which transmit the disease. Lowest mean population of whitefly(3.74/3leaves) and lowest YMV infected plant of 3.7\% was found in seed treatment with imidacloprid 600FS @ 5ml/kg of seed, installation of yellow sticky trap @ 50 traps/ha and spraying of diafenthiuron50\% WP @ $1 \mathrm{gm} /$ Lit with $41.74 \%$ increase in yield and $\mathrm{BC}$ ratio 1.86 followed by whitefly population of 6.22/3leaves and \% YMV affected plant of 5.38 in seed treatment with imidacloprid 600FS, installation of yellow sticky trap and spraying of acetamiprid 20 SP @ $0.3 \mathrm{gm} /$ Lit with $35.26 \%$ increase in yield and $\mathrm{BC}$ ratio of 1.82 as compared with control of whitefly population102.9/3leaves, $\%$ YMV affected plant of 38.44 and $\mathrm{BC}$ ratio of 1.45 . The whitefly population, \% disease incidence in other treatments, were more but \% increase in yield over control and $\mathrm{BC}$ ratio were lower than the above two treatments. Highest number of natural enemies like spider and lady bird beetle was found in control followed by neem oil, only seed treatment, yellow sticky trap and lower population of natural enemies in insecticide treated plots.

\section{Introduction}

Okra (Abelmoschus esculentus L. Moench) is one of the important and leading vegetable in India which is grown in an area of 528.37 thousand hectare with annual production of 6145.97 thousand MT and it is mainly grown for its green tender fruits. It is also an important vegetable of Odisha which is grown in an area of 63.96 thousand hectare with annual production of 565.18 thousand MT and takes a key position in nutritional and food security for the small and marginal farmers of Odisha. The above production both in Odisha and India is much less than the potential yield because of the lower crop productivity, which is due to incidence of pests including diseases. Among several diseases of Okra, yellow vein mosaic virus (YVMV) is the most severe one causing colossal losses by affecting the quality and yield of the fruit (Kalita and Dhawan, 2006). 
The disease is transmitted by whitefly (Bemisia tabaci) and the losses depend upon the age of the plant at the time of infection (Sastry and Singh, 1974; Bhagat, 2000). YVMV infects all the stages of the crops and severely reduces plant growth and yield of Okra. The infected plants are stunted and produce small sized pale yellow fruits (Arora et al., 2008). Okra yellow vein mosaic virus belong to the family geminiviridae and is a monopartite begomo virus associated with the small satellite DNA-a component both responsible for disease development (Briddon and Stanley, 2006; Jose and Usha, 2003).The symptom appear on the leaves as well as the fruit affecting both fruit yield and quality but may affect the crop at all growth stages (Venkataravanappa et al., 2013). The symptoms of the disease appear in varied forms as patched mottling of younger leaves followed by irregular and inter-veinal chlorosis on older leaves, small vein clearing at leaf margin, appearance of network of yellow vein surrounded by green patches in young leaves. Malformed or twisted fruits with smaller size, hard texture with more fibre content appears in severe incidence (Brunt et al., 1996). As YVMV is transmitted by whitefly (Bemisia tabaci Genn), management of the vector insect is the prime necessity for management of the disease. Indiscriminate use of organophosphates, carbamates and synthetic pyrethroids to manage vector population of whitefly results in the increase in cost of production, resistance built by the vector species leading to development of potent strains, breakdown of host resistance and residual toxicity in fruits and in the components of environment like soil and water (Rao et al., 2015). YVMV resistance has been broken down frequently in many popular varieties due to appearance of new strains of viruses or due to recombination in virus strains (Sanwaal et al., 2014; Kumari et al., 2018). There are many limitations for control of virus disease like YVMV, bad effects of indiscriminate use of chemical pesticides to manage the disease, lack of stable sources of resistance against the disease, frequent breakdown of the YVMV resistance in many varieties are among the major reasons for lack of proper disease management strategies. In this circumstances integration of both non-chemical and chemical methods is essential for ecofriendly and economic management of this disease. Keeping this in mind the present study was conducted to evaluate some eco-friendly IPM modules to manage the disease under MidCentral Table Land Zone of Odisha.

\section{Materials and Methods}

Field trials were conducted at Regional Research and Technology Transfer Station, Dhenkanal under Odisha University of Agriculture and Technology for two consecutive years in Kharif 2016 and 2017 with eight treatments (seven IPM modules along with one control). Okra cultivar Pusa Sawani was sown $60 \mathrm{~cm}$ x $45 \mathrm{~cm}$ spacing and plot size of $5 \mathrm{~m} \times 4 \mathrm{~m}$. Recommended agronomic practices were followed during the course of study. The various components of IPM module viz. Seed treatment, installation of yellow sticky traps and spraying of insecticides were combined in different treatments and presented in Table 1. First spraying of insecticide was done at 30 days after sowing and second spraying was done after 15 days. The crop was visited frequently to observe different types of yellow vein mosaic symptoms and observation on disease incidence were recorded at 30 and 60 days after sowing. But disease incidence recorded at 60 days after sowing was taken as final disease incidence and per cent disease incidence was assessed by recording the number of plants showing disease symptoms and total no of plants using the formula: Number of diseased plants/Total number of plant examined X 100. The population of 
whitefly acting as vector for disease transmission and natural enemies (spider and lady bird beetle: LBB) were also counted/ 3 leaves before and after spraying to assess the effect of insecticide on their population. The yield was calculated as $\mathrm{kg} / \mathrm{plot}$ by pulling the healthy fruit yield of 12 pickings done at 3-5 days interval and then calculated as $\mathrm{q} / \mathrm{ha}$. All the above data are subjected to statistical analysis for final conclusion.

\section{Results and Discussion}

The results pertaining to the effect of different IPM modules indicated that there was significant reduction in the population of whitefly in all the treatments as compared to the control in 5, 10 and 15 days after spraying. But the lowest number of whitefly (3.75/3leaves) was observed in $\mathrm{T}_{7}(\mathrm{ST}+\mathrm{YST}+$ diafenthiuron 50\% WP @ 1g/lit.) followed by 6.22/3leaves in $\mathrm{T}_{6}(\mathrm{ST}+\mathrm{YST}+$ acetamiprid 20SP@0.3g/lit.) over control of 102.9/3leaves. Other treatments showed whitefly population midway between control and the above two treatments (Table-2). The $\%$ disease incidence also followed the same trend of 3.7 in $\mathrm{T}_{7}(\mathrm{ST}+\mathrm{YST}+$ diafenthiuron 50\% WP @ 1g/lit.) followed by 5.38 in $\mathrm{T}_{6}$ (ST+ YST+ acetamiprid 20SP @ 0.3g/lit.) and $7.48,10.69,15.16,17.91$ and 23.07 respectively in all other treatments as compared to control of 38.44. The lowest damage in diafenthiuron was presumed to be due to the novel mode of action (inhibition of the oxidative phosphorylation i.e. ATP synthatase), translaminar activity, high selectivity towards beneficial insects.

The results obtained in the present trial regarding the effectiveness of diafenthiuron and acetamiprid in reducing the population of whitefly and consequent YMV affected plant is in conformity with the findings of Patel $e t$ al., (2010) who reported that diafenthiuron was most effective in reducing the population of whitefly followed by acetamiprid in cotton. The findings obtained in relation to the effect of acetamiprid and neem products in reducing the population of whitefly and \% disease incidence is in consonance with the results of Jambhulkar et al., (2013). Manju et al., (2018) reported effective control of whitefly population and consequent YVMV disease incidence in Okra with novel insecticides like acetamiprid, buprofezin, diafenthiuron, neem oil and imidacloprid along with increased yield and cost benefit ratio. The result in this study in relation to the effect of diafenthiuron in reducing the population of whitefly and yellow vein mosaic corroborates the finding of Ghosal and Chatterjee (2013) and in relation to yellow sticky trap is in conformity with the finding of Chakraborti et al., (2014).

Table.1 Details of the treatments and IPM modules used for the study

$$
\begin{array}{l|l}
\mathbf{T}_{1} & \text { Seed Treatment with Imidacloprid 600 FS @ } \mathbf{5 ~ m l} / \mathbf{K g} \text { (ST ) } \\
\hline \mathbf{T}_{\mathbf{2}} & \text { Installation of Yellow Sticky Trap @ 50 / ha (YST) } \\
\hline \mathbf{T}_{3} & \text { ST + YST } \\
\hline \mathbf{T}_{4} & \text { ST + YST + Neem Oil 0.15\% @ 2 ml / Lit. } \\
\mathbf{T}_{\mathbf{5}} & \mathrm{ST}+\text { YST + Buprofezin 25 SC @ 1 } \mathrm{ml} / \mathrm{Lit} . \\
\hline \mathbf{T}_{6} & \mathrm{ST}+\text { YST + Acetamiprid 20 SP @ 0.3 gm / Lit. } \\
\hline \mathbf{T}_{7} & \text { ST + YST + Diafenthiuron 50\% WP @ 1 gm / Lit. } \\
\hline \mathbf{T}_{8} & \text { Untreated Control }
\end{array}
$$


Table.2 Effect of IPM module on population of whitefly in Okra (pooled over Kharif, 2016 \& 17)

\begin{tabular}{|c|c|c|c|c|c|}
\hline \multirow[t]{2}{*}{ Tr. No } & \multirow[t]{2}{*}{ Treatments } & \multicolumn{4}{|c|}{ Whitefly /3leaves } \\
\hline & & 1DBS & 5DAS & 10DAS & 15DAS \\
\hline $\mathbf{T}_{1}$ & $\begin{array}{l}\text { Seed Treatment with Imidacloprid } 600 \text { FS @ } 5 \mathrm{ml} / \mathrm{Kg} \\
\text { (ST ) }\end{array}$ & $\begin{array}{l}27.76 \\
(5.32)^{*}\end{array}$ & $\begin{array}{l}23.35 \\
(4.89)\end{array}$ & $\begin{array}{l}19.45 \\
(4.48)\end{array}$ & $\begin{array}{l}15.05 \\
(3.96)\end{array}$ \\
\hline $\mathbf{T}_{2}$ & Installation of Yellow Sticky Trap @ 50 / ha (YST) & $\begin{array}{l}28.46 \\
(5.38)\end{array}$ & $\begin{array}{l}21.90 \\
(4.73)\end{array}$ & $\begin{array}{l}17.05 \\
(4.19)\end{array}$ & $\begin{array}{l}13.69 \\
(3.77)\end{array}$ \\
\hline $\mathbf{T}_{3}$ & $\mathrm{ST}+\mathrm{YST}$ & $\begin{array}{l}28.03 \\
(5.34)\end{array}$ & $\begin{array}{l}16.86 \\
(4.17)\end{array}$ & $\begin{array}{l}15.24 \\
(3.97)\end{array}$ & $\begin{array}{l}13.12 \\
(3.71)\end{array}$ \\
\hline $\mathbf{T}_{4}$ & ST+YST+ Neem Oil 0.15\%@ 2 ml / Lit. & $\begin{array}{l}27.83 \\
(5.32)\end{array}$ & $\begin{array}{l}10.78 \\
(3.36)\end{array}$ & $\begin{array}{c}9.59 \\
(3.18)\end{array}$ & $\begin{array}{l}10.41 \\
(3.30)\end{array}$ \\
\hline $\mathbf{T}_{5}$ & ST + YST + Buprofezin 25 SC @ 1 ml / Lit. & $\begin{array}{l}28.60 \\
(5.39)\end{array}$ & $\begin{array}{c}8.92 \\
(3.07)\end{array}$ & $\begin{array}{c}8.34 \\
(2.97)\end{array}$ & $\begin{array}{c}8.87 \\
(3.06)\end{array}$ \\
\hline$T_{6}$ & $\mathrm{~T}_{7}-\mathrm{ST}+\mathrm{YST}+$ Acetamiprid 20 SP @ 0.3 gm / Lit. & $\begin{array}{l}28.25 \\
(5.36)\end{array}$ & $\begin{array}{l}6.25 \\
(2.60)\end{array}$ & $\begin{array}{l}5.06 \\
(2.36)\end{array}$ & $\begin{array}{c}6.22 \\
(2.59)\end{array}$ \\
\hline $\mathbf{T}_{7}$ & ST + YST + Diafenthiuron 50\% WP @ 1 gm / Lit. & $\begin{array}{l}27.95 \\
(5.33)\end{array}$ & $\begin{array}{c}3.54 \\
(2.01)\end{array}$ & $\begin{array}{c}2.66 \\
(1.78)\end{array}$ & $\begin{array}{c}3.75 \\
(2.06)\end{array}$ \\
\hline $\mathbf{T}_{8}$ & Untreated Control & $\begin{array}{l}30.60 \\
(5.58)\end{array}$ & $\begin{array}{l}42.02 \\
(6.52)\end{array}$ & $\begin{array}{l}68.32 \\
(8.30)\end{array}$ & $\begin{array}{c}102.9 \\
(10.17)\end{array}$ \\
\hline & $\operatorname{SEM}( \pm)$ & 0.92 & 1.09 & 0.64 & 1.19 \\
\hline & $\mathrm{CD}(\mathrm{p}=0.05)$ & 2.77 & 3.27 & 1.92 & 3.58 \\
\hline
\end{tabular}

* Figures in parentheses are square root transformed values.

DBS: Days before spraying, DAS: Days after spraying.

Table.3 Effect of IPM module on population of natural enemies in Okra (pooled over Kharif, 2016 \& 17)

\begin{tabular}{|c|c|c|c|c|c|c|c|c|c|}
\hline \multirow[t]{3}{*}{ Tr. No } & \multirow[t]{3}{*}{ Treatments } & \multicolumn{8}{|c|}{ Natural enemy population after first spraying } \\
\hline & & \multicolumn{2}{|c|}{ 1DBS } & \multicolumn{2}{|c|}{ 5DAS } & \multicolumn{2}{|c|}{ 10DAS } & \multicolumn{2}{|c|}{ 15DAS } \\
\hline & & Spider & LBB & Spider & LBB & Spider & LBB & Spider & LBB \\
\hline$T_{1}$ & $\begin{array}{l}\text { Seed Treatment with Imidacloprid } 600 \text { FS } \\
\text { @ } 5 \mathrm{ml} / \mathrm{Kg}(\mathrm{ST})\end{array}$ & $\begin{array}{c}8.50 \\
(3.00)^{*}\end{array}$ & $\begin{array}{l}16.74 \\
(4.15)\end{array}$ & $\begin{array}{c}8.95 \\
(3,07)\end{array}$ & $\begin{array}{l}18.15 \\
(4.32)\end{array}$ & $\begin{array}{l}10.94 \\
(3.38)\end{array}$ & $\begin{array}{l}18.95 \\
(4.41)\end{array}$ & $\begin{array}{l}13.02 \\
(3.68)\end{array}$ & $\begin{array}{l}21.11 \\
(4.65)\end{array}$ \\
\hline $\mathbf{T}_{2}$ & $\begin{array}{l}\text { Installation of Yellow Sticky Trap @ } 50 \text { / } \\
\text { ha (YST) }\end{array}$ & $\begin{array}{c}9.78 \\
(3.21)\end{array}$ & $\begin{array}{l}17.00 \\
(4.18)\end{array}$ & $\begin{array}{l}8.43 \\
(2.99)\end{array}$ & $\begin{array}{l}18.05 \\
(4.31)\end{array}$ & $\begin{array}{l}10.37 \\
(3.30)\end{array}$ & $\begin{array}{l}18.76 \\
(4.39)\end{array}$ & $\begin{array}{l}11.12 \\
(3.41)\end{array}$ & $\begin{array}{l}20.01 \\
(4.53)\end{array}$ \\
\hline $\mathbf{T}_{3}$ & $\mathrm{ST}+\mathrm{YST}$ & $\begin{array}{c}8.78 \\
(3.05)\end{array}$ & $\begin{array}{l}16.66 \\
(4.14)\end{array}$ & $\begin{array}{c}7.62 \\
(2.85)\end{array}$ & $\begin{array}{l}17.44 \\
(4.24)\end{array}$ & $\begin{array}{c}9.27 \\
(3.12)\end{array}$ & $\begin{array}{l}17.75 \\
(4.27)\end{array}$ & $\begin{array}{l}10.07 \\
(3.25)\end{array}$ & $\begin{array}{l}18.46 \\
(4.35)\end{array}$ \\
\hline $\mathbf{T}_{4}$ & ST+YST + Neem Oil 0.15\% @ 2 ml / Lit. & $\begin{array}{c}9.00 \\
(3.08)\end{array}$ & $\begin{array}{l}16.88 \\
(4.17)\end{array}$ & $\begin{array}{l}7.22 \\
(2.78)\end{array}$ & $\begin{array}{l}15.21 \\
(3.96)\end{array}$ & $\begin{array}{c}9.98 \\
(3.24)\end{array}$ & $\begin{array}{l}17.86 \\
(4.28)\end{array}$ & $\begin{array}{l}11.33 \\
(3.44)\end{array}$ & $\begin{array}{l}20.56 \\
(4.59)\end{array}$ \\
\hline$T_{5}$ & $\begin{array}{l}\text { ST + YST + Buprofezin 25 SC @ } 1 \text { ml / } \\
\text { Lit. }\end{array}$ & $\begin{array}{c}8.78 \\
(3.05)\end{array}$ & $\begin{array}{l}16.62 \\
(4.14)\end{array}$ & $\begin{array}{c}5.82 \\
(2.51)\end{array}$ & $\begin{array}{l}15.22 \\
(3.96)\end{array}$ & $\begin{array}{l}7.95 \\
(2.91)\end{array}$ & $\begin{array}{l}16.00 \\
(4.06)\end{array}$ & $\begin{array}{l}8.83 \\
(3.05)\end{array}$ & $\begin{array}{l}16.26 \\
(4.09)\end{array}$ \\
\hline$T_{6}$ & $\begin{array}{l}\mathrm{T}_{7}-\mathrm{ST}+\mathrm{YST}+\text { Acetamiprid } 20 \mathrm{SP} @ 0.3 \\
\mathrm{gm} / \text { Lit. }\end{array}$ & $\begin{array}{c}8.11 \\
(2.93)\end{array}$ & $\begin{array}{l}16.48 \\
(4.12)\end{array}$ & $\begin{array}{c}4.80 \\
(2.30)\end{array}$ & $\begin{array}{l}11.96 \\
(3.53)\end{array}$ & $\begin{array}{c}6.78 \\
(2.70)\end{array}$ & $\begin{array}{l}12.11 \\
(3.55)\end{array}$ & $\begin{array}{l}7.95 \\
(2.91)\end{array}$ & $\begin{array}{l}12.56 \\
(3.61)\end{array}$ \\
\hline $\mathbf{T}_{7}$ & $\begin{array}{l}\text { ST + YST + Diafenthiuron 50\% WP @ } 1 \\
\text { gm / Lit. }\end{array}$ & $\begin{array}{c}8.79 \\
(3.05)\end{array}$ & $\begin{array}{l}16.82 \\
(4.16)\end{array}$ & $\begin{array}{l}5.65 \\
(2.48)\end{array}$ & $\begin{array}{l}13.74 \\
(3.77)\end{array}$ & $\begin{array}{c}8.61 \\
(3.02)\end{array}$ & $\begin{array}{l}14.39 \\
(3.86)\end{array}$ & $\begin{array}{l}10.39 \\
(3.30)\end{array}$ & $\begin{array}{l}15.48 \\
(4.00)\end{array}$ \\
\hline \multirow[t]{3}{*}{$T_{8}$} & Untreated Control & $\begin{array}{c}9.71 \\
(3.20)\end{array}$ & $\begin{array}{l}17.39 \\
(4.23)\end{array}$ & $\begin{array}{c}8.84 \\
(3.06)\end{array}$ & $\begin{array}{l}18.61 \\
(4.37)\end{array}$ & $\begin{array}{l}18.27 \\
(4.33)\end{array}$ & $\begin{array}{l}21.21 \\
(4.66)\end{array}$ & $\begin{array}{l}22.70 \\
(4.82)\end{array}$ & $\begin{array}{l}30.46 \\
(5.56)\end{array}$ \\
\hline & & 0.32 & 0.44 & 0.33 & 0.42 & 0.23 & 0.76 & 0.40 & 0.91 \\
\hline & $\mathrm{CD}(\mathrm{p}=0.05)$ & 0.97 & 1.34 & 1.00 & 1.36 & 0.70 & 2.30 & 1.21 & $(2.74$ \\
\hline
\end{tabular}

* Figures in parentheses are square root transformed values. 
Table.4 Effect of IPM module on YMV incidence, yield \& economics in Okra(pooled over Kharif, 2016 \& 17)

\begin{tabular}{|c|c|c|c|c|c|}
\hline $\begin{array}{l}\text { Tr. } \\
\text { No }\end{array}$ & Treatments & $\begin{array}{l}\% \text { YMV } \\
\text { affected plant }\end{array}$ & $\begin{array}{l}\text { Yield } \\
\text { (q/ha) }\end{array}$ & $\begin{array}{l}\text { Increase } \\
\text { over control }\end{array}$ & B:C ratio \\
\hline $\mathbf{T}_{1}$ & $\begin{array}{l}\text { Seed Treatment with Imidacloprid 600 FS @ } \\
5 \mathrm{ml} / \mathrm{Kg}(\mathrm{ST})\end{array}$ & $\begin{array}{c}23.07 \\
(29.74)^{*}\end{array}$ & 102.5 & 9.08 & 1.56 \\
\hline $\mathbf{T}_{2}$ & $\begin{array}{l}\text { Installation of Yellow Sticky Trap @ } 50 \text { / ha } \\
\text { (YST) }\end{array}$ & $\begin{array}{c}17.91 \\
(25.43)\end{array}$ & 105.1 & 11.84 & 1.54 \\
\hline $\mathbf{T}_{3}$ & $\mathrm{ST}+\mathrm{YST}$ & $\begin{array}{l}15.16 \\
(22.23)\end{array}$ & 108.3 & 15.25 & 1.58 \\
\hline $\mathbf{T}_{4}$ & ST+YST+ Neem Oil 0.15\%@2 ml / Lit & $\begin{array}{c}10.69 \\
(18.98)\end{array}$ & 114.4 & 21.74 & 1.63 \\
\hline $\mathbf{T}_{5}$ & ST+YST+ Buprofezin 25 SC @ 1 ml / Lit. & $\begin{array}{c}7.48 \\
(15.65)\end{array}$ & 119.1 & 26.74 & 1.72 \\
\hline$T_{6}$ & ST + YST + Acetamiprid 20 SP @ 0.3 gm / Lit. & $\begin{array}{c}5.38 \\
(13.55)\end{array}$ & 127.1 & 35.26 & 1.82 \\
\hline $\mathbf{T}_{7}$ & $\begin{array}{l}\text { ST + YST + Diafenthiuron 50\% WP @ } 1 \text { gm / } \\
\text { Lit. }\end{array}$ & $\begin{array}{c}3.7 \\
(10.82)\end{array}$ & 133.2 & 41.74 & 1.86 \\
\hline \multirow[t]{3}{*}{$\mathbf{T}_{8}$} & Untreated Control & $\begin{array}{c}38.44 \\
(38.75)\end{array}$ & 93.97 & - & 1.45 \\
\hline & $\operatorname{SEM}( \pm)$ & 0.59 & 1.30 & - & - \\
\hline & $\mathrm{CD}(\mathrm{p}=0.05)$ & 1.7 & 3.92 & - & - \\
\hline
\end{tabular}

*Figures in parentheses are angular transformed values

Highest number of natural enemy of spider (22.7) and $\operatorname{LBB}(30.46)$ was found in control plot followed by only ST of spider(13.02) and LBB (21.11), ST+ YST + Neem oil of spider (11.33) and $\mathrm{LBB}(20.56)$ and YST treated plot of spider (11.12) and LBB (20.01) and ST+YST treated plot of spider(10.07) and LBB (18.46). Among insecticides highest number of natural enemy spider (8.83) and LBB(16.26) was found in buprofezin treated plot followed by diafenthiuron of spider (10.39) and LBB (15.48) and acetamiprid of spider (7.95) and LBB (12.56) indicating comparatively less bad effects of insecticides on natural enemies..

Highest yield of $133.2 \mathrm{q} / \mathrm{ha}$ and increased in yield over control $(41.74 \%)$ and $\mathrm{BC}$ ratio of 1.86 was obtained in $\mathrm{T}_{8}(\mathrm{ST}+\mathrm{YST}+$ diafenthiuron 50\% WP @ 1g/lit.) followed by $\mathrm{T}_{7}$ (ST+ YST+ acetamiprid 20SP @ 0.3g/lit.) of $127.1 \mathrm{q} / \mathrm{ha}, 35.26 \%$ increase in yield over control and $\mathrm{BC}$ ratio of 1.82 as compared with control yield of $93.97 \mathrm{q} / \mathrm{ha}$ and $\mathrm{BC}$ ratio of 1.45. The results in relation to yield, $\%$ increase in yield over control and $\mathrm{BC}$ ratio of different treatments is in conformity with the finding of Ghosal and Chatterjee (2013), Jambulkar et al., (2013) and Manju et al., (2018).

Hence it may be concluded that ,Okra seed treated with imidacloprid 600 FS @ 5ml/kg followed by installation of yellow sticky trap (YST) 50/ha and spraying of diafenthiuron 50\% WP @ 1 g/litre exhibit lowest number of white fly (3.54, 2.66 and 3.75 after 5, 10 and 15 DAS, respectively) with more number of natural enemy (spider and lady bird beetle), lowest \% YMV affected plant (3.7), highest yield (133.2 q/ha) and B:C ratio of 1.86 can be recommended to manage yellow vein mosaic disease and its vector whitefly population in India.

\section{References}

Arora, D., Jindal, S.K. and Singh, K. 2008. Genetics of resistance to yellow vein mosaic virus in inter varietal crosses of okra (Abelmoschus esculentus L. Moench). SABRAO Journal of Breeding and 
Genetics 40:93-103

Bhagat, A.P. 2000. Effect of Okra yellow vein mosaic virus (BYVMV) on growth and yield of Okra. Journal of Mycology and Plant Pathology 30: 110-111.

Briddon, R.W. and Stanley, J. 2006.Subviral agents associated with plant single stranded DNA viruses. Virology, 344: 198-210.

Brunt , A.A., Crabtree, K., Dallwitz, M.J., Gibbs, A.J., Watson, L. and Zurcher, E.J. 1996. Plant viruses online: descriptions and lists from the VIDE database. http://biology.anu.edu.au/Groups/MES/vide /

Chakraborti, S., Sarkar, Pijush K. and Chakraborty, A. 2014. Assessing the impacts of safer management strategies for okra yellow vein mosaic virus (OYVMV) and its white fly vector with emphasis on under-storey repellent crop. Journal of Entomological Research, 38(1): 7-15.

Ghosal, A. and Chatterjee, M.L.2013. Management of okra yellow vein mosaic virus by chemical control of Bemisia tabaci gennadius. Indian Journal of Entomology 75(3):236-238.

Jambhulkar, P.P., Singh, Virendra, Ramesh Babu, S. and Yadav, R.K. 2013. Insecticides and Bioproducts against Whitefly Population and Incidence of Yellow vein mosaic virus in Okra. Indian Journal of Plant Protection 41(3): 253-256.

Jose, J. and Usha, R. 2003. Extraction of geminiviral DNA from a highly mucilaginous plant (Abelmoschus esculentus). Plant Molecular Biology Reporter, 18:355.

Kalita, M.K. and Dhawan, P. 2006. Management of yellow vein mosaic and leaf curl diseases of okra by adjusting date of sowing and row to row spacing. Indian Journal of Agricultural Sciences 76: 762-765.
Kumari, M., Solankey, S.S., Kumar, M., Akhtar, S. and Pallavi, N. 2018. Assessment of Okra Genotypes for Yellow Vein Mosaic Virus Tolerance. International Journal of Current Microbiology and Applied Sciences 7:1470-1475.

Manju, K.P.,Vijayalaksmi, K., Babu, S.B. and Anitha, K.2018.Management of Whitefly, Bemisia tabaci and Whitefly Transmitted Okra Yellow Vein Mosaic Virus (OYVMV) in Okra. International Journal of Current Microbiology and Applied Science 6:1676-1681.

Patel, Yogesh, Sharma, H.P. and Das, S.B. 2010 Novel insecticides for management of white fly (Bemisia tabaci Genn.) on cotton. Ann. Pl. Protection Sciences, 18(1): 6-9.

Rao, G.V.R., Kumari, B.R., Sahrawat, K.L. and Wani, S.P. 2015. Integrated Pest Management (IPM) for Reducing Pesticide Residues in Crops and Natural Resources. In: A.K. Chakravarthy (ed.), New Horizons in Insect Science: Towards Sustainable Pest Management. P: 307-412. DOI 10.1007/978-81- 322-2089-3-35, OSpringer India.

Sanwal, S.K., Singh, M., Singh, B. and Nai, P.S. 2014. Resistance to yellow vein mosaic virus and okra enation leaf curl virus: Challenges and future strategies. Current Science, 106(11): 1470-1471

Sastry, K.S.M. and Singh, S. J. 1974. Effect of yellow vein mosaic virus infection on growth and yield of okra crop. Indian phytopathology 27: 294-297.

Venkataravanappa, V., Reddy, L.C.N. and Reddy, M.K. 2013. Begomovirus characterization and development of phenotypic and DNAbased diagnostics for screening of okra genotype resistance against Okra yellow vein mosaic virus. Biotechnology, 3: 461470 .

\section{How to cite this article:}

Panigrahi, D., B.C. Dhir, S. Samal, B.K. Routray and Pani, B. K. 2020. Evaluation of IPM Module for Management of Yellow Vein Mosaic Virus in Okra under Mid-Central Table Land Zone of Odisha. Int.J.Curr.Microbiol.App.Sci. 9(07): 2575-2580.

doi: https://doi.org/10.20546/ijcmas.2020.907.303 